\title{
UMA ABORDAGEM DA DRAMATURGIA DE MARIA CLARA MACHADO: ENTRE GÊNERO, PSICANÁLISE E REGIMES DE VERIDICÇÃO
}

\author{
AN APPROACH OF MARIA CLARA MACHADO'S \\ DRAMATURGY: BETWEEN GENDER, PSYCHOANALYSIS \\ AND REGIMES OF VERIDICTION
}

\begin{abstract}
Sidmar Silveira Gomes*
Resumo: Inspirado na arqueogenealogia de Michel Foucault, este trabalho se interessa por inventariar de que modo, ao longo de seus deslocamentos, emergências e contingências, a produção dramatúrgica de Maria Clara Machado, recortada, à princípio, pela articulação entre as categorias de gênero e de constituição $p s i$, evidencia, de forma geral, práticas de governamento de tipo artístico-pedagógico no interior das práticas teatrais, não raro autodeclaradas imunes e contrárias a ações dirigistas e não libertárias. Trata-se, portanto, de uma empreitada crítica do presente por meio de uma revisão do passado. Para tanto, esta pesquisa conta com arquivo organizado a partir de materiais discursivos oferecidos por jornais nacionais que circularam na primeira metade do século XX, somados a declarações da própria Maria Clara Machado e a textos de comentadores de sua obra.
\end{abstract}

Palavras-Chave: Maria Clara Machado. Dramaturgia. Teatro Infantil. Governamento

\begin{abstract}
Inspired by Michel Foucault's archaeo-genealogy method, this work is interested in inventory, along its displacements, emergencies and contingencies, how Maria Clara Machado's dramaturgical production, primarily cut by the articulation between the categories of gender and psy constitution, generally highlights the governmentality practices of artistic-pedagogical type within theatrical practices, often self-declared immune and contrary to dirigiste and non-libertarian actions. Therefore, it is a critical undertaking of the present through a revision of the past. For this purpose, this research lays on a file organized from discursive materials offered by national newspapers that circulated in the first half of the twentieth century, in addition to statements by Maria Clara Machado and texts by commentators of her work.
\end{abstract}

Keywords: Maria Clara Machado. Dramaturgy. Children's Theater. Governmentality.

\section{Introdução}

Nadie sabe el pasado que le espera Tania Brugera

As edições de 16 e 17 de abril de 1962 do jornal carioca Última Hora trazem em sua seção teatral críticas complementares do jornalista Paulo Francis acerca da recémestreada montagem de A Gata Borralheira pelo grupo $\mathrm{O}$ Tablado, com direção e adaptação de Maria Clara Machado. Francis inicia seu texto por meio de uma leitura do conto que originou o espetáculo, Cinderela, enviesada pela perspectiva de interpretações psicanalíticas do nascimento e da infância à luz de heróis como Moisés, Édipo etc., tendo em vista reiterar a riqueza do texto original e, principalmente, denunciar a indigência da imaginação de Maria Clara Machado que, em sua montagem de A Gata Borralheira, segundo o crítico, não teria reinterpretado a fábula, "seguindo mais ou menos o original, passando a fada a ser apenas madrinha, sem qualquer componente sobrenatural" (FRANCIS, 1962a, p. 43), usando o original meramente para uma "exibição colegial". Enveredando por uma interpretação no escopo de gênero, Francis relata que na montagem as "fêmeas eram agressivas e famintas de casamento, ao passo que os homens, embora partilhem o segundo intento, são passivos e vagos" (FRANCIS, 1962a, p. 43).

*Doutor em Educação pela Faculdade de Educação da Universidade de São Paulo (FEUSP). Atualmente é programador cultural do Sesc-SP.E-mail: sidmar.gomes@uol.com.br 
Sobre a configuração dos personagens, na opinião de Francis, "vai-se ao príncipe, apalermado acima e além do dever, a um primeiro-ministro da escola tatibitate de interpretação, mais infantilizado do que qualquer criança jamais poderá ser. Os outros tipos seguem a linha geral de caricatura" (FRANCIS, 1962b, p. 08).

Esquecidas por grande parte dos estudiosos e exaltadores da obra de Maria Clara Machado, afeitos a ressaltarem apenas as positividades ditas sobre aquela que, de forma unânime, delegam ímpar importância à configuração das características do teatro infantil nacional, as críticas escritas pela pena de Paulo Francis, despertaram irritação em Maria Clara Machado. Por suas palavras: "dizia [Paulo Francis] que o texto nada tinha a ver com o dos irmãos Grimm e que eu deveria reler a história. E eu lá queria saber de Grimm, a história original era apenas uma vaga referência" (MACHADO, 1994, p. 24).

Ao partir dessa querela histórica, a presente reflexão se debruça sobre uma revisão histórico-política da obra da diretora e dramaturga Maria Clara Machado tendo como disparadores os temas do papel social de gênero e da psicanálise, categorias que tangenciam seu legado, ainda que olvidadas por parcela significativa, se não total, dos trabalhos reflexivos que se ocupam da artista carioca. Ao tomar como inspiração a arqueogenealogia de Michel Foucault, este trabalho se interessa por inventariar de que modo, ao longo de seus deslocamentos, emergências e contingências, a produção teatral de Maria Clara Machado, recortada, à princípio, pela articulação entre gênero e constituição psi, evidenciaria, de forma geral, práticas de governamento de tipo artístico-pedagógico no interior das práticas teatrais, as quais corroborariam para a tese de que para se governar sujeitos seria necessário conhecê-los em seu íntimo (ROSE, 2011).

Vale ressaltar que este não se trata de um texto que intenta inaugurar novas contribuições significativas aos temas do gênero social e da constituição psi, mas de lançar luz sobre duas categorias que circulam em evidência na contemporaneidade e que podem ser localizadas na obra de uma diretora e dramaturga de grande envergadura para a história do teatro infantil brasileiro, como espécie de disparadores para uma empreitada crítica do presente a partir de uma revisão do passado. Quase que escolhidas aleatoriamente, tais categorias poderiam ser outras - como se verá adiante, por exemplo, uma mirada cristã sobre a vida, a exaltação do bem subjacente a apelativas imagens simbólicas e poéticas, ou a educação pelos sentidos. Ainda que fossem modificadas as categorias em jogo, diga-se os panos de fundo para a discussão, os interesses desta reflexão se manteriam, a saber: uma análise das práticas de governamento de cunho artístico-pedagógico no interior da maquinaria teatral, não raro autodeclarada imune e contrária a ações dirigistas e não libertárias.

Foucault apresenta que arqueologia e genealogia estruturam-se sobre o seguinte pressuposto comum: "escrever a história sem referir a análise à instância fundadora do sujeito" (CASTRO, 2016, p. 185). A genealogia buscaria descrever a constituição das verdades, interessando-se não por perguntar por quê, mas sim como. A arqueologia, por sua vez, descreveria "os discursos como práticas específicas no elemento do arquivo" (FOUCAULT, 1984, p. 174). O interesse de Foucault pelo uso da palavra arqueologia estaria pautado nos seguintes motivos: arche, em grego, significa começo; em francês archive, que representa a maneira como os elementos discursivos teriam sido registrados e poderiam ser extraídos; por fim, seu objetivo seria o de reconstruir um caminho histórico em suas dimensões políticas, econômicas, sexuais. 
Assim, meu projeto não é o de fazer um trabalho de historiador, mas descobrir por que e como se estabelecem relações entre os acontecimentos discursivos. Se faço isso, é com o objetivo de saber o que somos hoje. [...] Penso que há, em nossa sociedade e naquilo que somos, uma dimensão histórica profunda e, no interior desse espaço histórico, os acontecimentos discursivos que se produziriam há séculos ou há anos são muito importantes. Somos inextricavelmente ligados aos acontecimentos discursivos. Em um certo sentido, não somos nada além do que aquilo que foi dito, há séculos, meses, semanas... (FOUCAULT, 2006, p. 258).

Dessa forma, três grandes regras metodológicas operam no conjunto genealógico: os princípios de descontinuidade, de especificidade e de exterioridade (CASTRO, 2016). Por arqueogenealogia pode-se entender o percurso de problematizar um objeto:

Perguntar-se como teria sido pensado, em uma dada época, um ser (é a tarefa daquilo a que se chamava a arqueologia), e analisar (trabalho da genealogia, no sentido nietzchiano do termo) e descrever as diversas práticas sociais, científicas, éticas, punitivas, medicais etc., que tiveram como correlato o facto de o ser ter sido pensado assim" (VEYNE, 2009, p. 113).

Inspirada pela arqueogenealogia foucaultiana, organizada pelo trabalho sobre o arquivo e interessada na reconstituição de toda uma rede de alianças, de comunicações e pontos de apoio, este estudo busca sair do interior da obra de Maria Clara Machado, partindo de algo exterior e geral, para inventariar as relações de saber-poder estabelecidas em seu interior. Disso, o crivo teórico-metodológico aqui apresentado pretende analisar quais são os efeitos de real efetivamente marcados, produzidos, induzidos pelos jogos de veridicção relativos às práticas dramatúrgicas de Machado, tendo em vista a constituição da experiência de sujeitos e de suas próprias verdades. Para isso, parte-se da tese de que os discursos em excesso acerca da obra da autora e diretora carioca, as repetições incessantes em torno de uma realidade já consentida, escamoteariam o ponto forte do real, em razão do governamento da infância (RESENDE, 2015), tomando governamento como ponto de intersecção "entre as tecnologias de dominação sobre os outros e as tecnologias de si” (FOUCAULT, 2004, p. 324). Como apresenta Rose (2011), para pertencer ao verdadeiro, são necessários aparatos complexos de verdade, nos quais estariam contidos fatos e argumentos imbricados em complexas alianças de processos de persuasão que objetivariam uma audiência interessada pela verdade.

Nessa perspectiva, a presente pesquisa não se apresenta como contracorrente à história já conhecida da obra de Maria Clara Machado, mas como uma espécie de giro e desvio daquilo que, nessa corrente, vislumbra-se como natural e já sabido. Esse olhar outro para o passado, estranhando o que parecia próximo, verossímil e familiar, objetiva, conforme já dito, uma crítica ao presente e o reavivamento de um legado que parecia adormecido.

Assim sendo, parte-se do entendimento das práticas teatrais, aqui recortadas pelo trabalho dramatúrgico de Maria Clara Machado, como dispositivo privilegiado de condução de condutas. Uma vez endereçada não apenas à racionalização da existência, mas sobretudo à exploração dos sentidos e da sensibilidade, as práticas teatrais direcionadas à criança, conforme Gomes (1967, p. 3), objetivariam "despertar a 
sensibilidade infantil para o belo, o harmonioso, incutindo o bom gôsto às crianças, e, por que não dizer, aprimoramento geral". Portanto, as práticas teatrais como um todo, não apenas aquelas endereçadas à criança, possibilitariam alterar a forma pela qual seria possível pensar-se as pessoas, seus valores, leis e demais diretrizes existenciais, logo, configurar-se-iam como campo de estratégia de práticas de governo das ações e das condutas de si e dos outros. Essa forma de se pensar as pessoas seria pautada, sobretudo, pelo interesse de transformar o indivíduo via a evocação da consciência e de seu desejo de constantemente melhorar. Nesse contexto, as práticas teatrais e o que Foucault denominou como tecnologias do self encontrariam íntima relação:

[Tecnologias do self] permitem aos indivíduos realizar, seja por seus próprios meios, seja com a ajuda de outros, uma série de operações sobre seus próprios corpos e almas, pensamentos, conduta e modo de ser, de forma a transformar a si mesmos e fim de atingir um certo estado de felicidade, pureza, sabedoria, perfeição ou imortalidade (FOUCAULT, 1988, p. 18).

Para a empreitada acima apresentada, o presente estudo vale-se do material discursivo oferecido por jornais que circularam na primeira metade do século XX, como os cariocas Correio da Manhã e Última Hora, fontes que consistem em um manancial de registros do cotidiano da então capital do país, celeiro das práticas inaugurais do teatro infantil, somados a declarações da própria Maria Clara Machado, colhidas de diferentes fontes, tais como biografias da autora, entrevistas etc., além de textos de comentadores de sua obra.

Por fim, o arquivo que interessa ao presente estudo será tomado não somente por seu entendimento como poeira do tempo, mas, sobretudo, pela perspectiva do que dele se faria no presente, conforme nos lembra a artista cubana Tania Brugera em epígrafe apresentada. A inspiração para o uso desse arquivo é fruto da aleatoriedade com a qual observamos os conjuntos, as seriações e as rarefações do que foi dito, além de como observamos suas dispersões, descontinuidades e regularidades.

Antes de prosseguir, uma ressalva é necessária. Ao longo do corpo desta reflexão opta-se pela substituição do conceito teatro, o qual soaria como um universal, pela ideia de práticas teatrais. As práticas, de acordo com o pensamento de inspiração foucaultiana, diriam respeito "à racionalidade ou a regularidade que organiza o que os homens fazem, que têm um caráter sistemático (saber, poder, ética) e geral (recorrente) e, por isso, constituem uma 'experiência' ou um 'pensamento"' (CASTRO, 2016, p. 338). Estariam contempladas, portanto, não apenas as práticas atinentes aos processos criativos, mas também os discursos e as racionalidades a eles inerentes.

\section{Os primórdios de $\mathrm{O}$ Tablado}

Maria Clara Machado nasceu em Belo Horizonte em 1921, mudando-se aos quatro anos de idade para o Rio de Janeiro. Filha do escritor e crítico Aníbal Machado, a autora revela que dois acontecimentos marcaram sua infância, imprimindo ecos em suas obras: a natureza vivida na fazenda de seu avô e a morte de sua mãe.

Minha mãe tinha 28 anos quando esperou o sexto filho. Nasceu um menino, mas ambos morreram. Isto foi em 1930. Eu tinha nove anos. Era estranho ser tão abraçada e beijada sem saber por quê. Ou melhor, eu sabia, mas tinha que guardar para mim (MACHADO, 1991, p. 20). 
Mediante a falta da mãe, segundo a autora, sua necessidade de afeto materno foi transferida para as freiras do colégio: apegava-se às mais bonitas e místicas.

A religião me fazia imaginar as ações mais incríveis. Além de colocar milho no sapato, para sofrer um pouco por amor a Jesus, eu queria ser missionária; mas uma missionária diferente. Ia tomar um avião cheio de bíblias e despejá-las na selva para os índios se converterem (MACHADO, 1991, p. 23).

Integrante do bandeirantismo quando adolescente, Machado tomou contato com o teatro nesse período. À noite, depois dos trabalhos, as integrantes, à volta de uma fogueira, dançavam, contavam histórias e representavam, desde Joana D'Arc e Maria Quitéria até mímica e palhaçadas.

Em 1941 Machado foi escolhida para representar o Brasil em uma reunião internacional nos Estados Unidos. Após sete meses naquele país, foi convidada por Cândido Portinari, amigo de seu pai que estava pintando alguns painéis na biblioteca do Congresso Americano, para ficar até o final do ano em sua companhia. Nos Estados Unidos, Machado tomou contato com o movimento teatral do país.

Sua primeira aproximação com o Patronato da Gávea, onde mais tarde seria fundado O Tablado, também aconteceu por conta do bandeirantismo.

Através do bandeirantismo fui parar no Patronato Operário da Gávea, instituição de caridade dirigida por um grupo de senhoras da sociedade. Fui trabalhar no ambulatório. Tinha que aprender a dar injeção, ser assistente social, cuidar das crianças que moravam nas favelas que na época existiam em volta do Patronato (foi a época das bíblias jogadas do avião) (MACHADO, 1991, p. 27).

A autora lembra que durante a Segunda Guerra Mundial, por volta de 1940, as mulheres tinham que contribuir de alguma forma. Ela tentou ser enfermeira, mas descobriu não ter vocação. Deixou a enfermagem e foi distrair os meninos da favela, jogando futebol. Nesse contexto, Maria Clara se interessou pelo teatro de bonecos, descoberto no Instituto Pestalozzi: "Pluft, o fantasminha, O Boi e o Burro no caminho de Belém, Marroquinhas Fru-Fru tiveram suas primeiras versões para o teatro de bonecos. Inventei um anti-herói, o professor Bigode, que era o apresentador do teatro" (Machado, 1991, p. 28).

Ao seguir a vontade de seu pai, Machado foi trabalhar como datilógrafa, primeiro em uma empresa de aviação e depois no Conselho Britânico. Para escapar da burocracia e da máquina de escrever, ela começou a fazer espetáculos com bonecos nos aniversários das crianças, ganhando pouco, mas executando com prazer suas encenações. Em decorrência dos bonecos, Machado montou um ateliê na garagem de sua casa, a famosa 487 da Visconde de Pirajá, em Ipanema. Os domingos da 487 eram um ponto de encontro entre artistas, intelectuais, políticos etc., que se reuniam para discutir sobre arte e os destinos do país e do mundo.

Jean Babille, famoso bailarino, Albert Camus, Pablo Neruda, Maria Helena Vieira da Silva, Dante Milano, Murilo Mendes, Vinicius de Moraes, Carlos Drummond de Andrade, Adalgisa e Ismael Nery, Di Cavalcanti, Goeldi, Guignard, Portinari e todos os novos que surgiam na época, Otto Lara Rezende, Paulinho Mendes Campos, Rubem 
Braga, João Cabral de Mello Neto, Scliar, Fayna, Glauco Rodrigues, Anna Letycia, Tonia Carrero e muitos e muitos outros frequentaram os domingos da 487 (MACHADO, 1991, p. 29).

Seu pai, o bem relacionado Aníbal Machado, dizia-se marxista convicto. No entanto, educava suas filhas em colégios de freiras. O escritor afirmava ser marxista, do pescoço para cima, e cristão, do pescoço para baixo.

Esta divisão de meu pai foi bastante difícil e conflitante para mim. Discutíamos muito e passei a mocidade cheia de dúvidas entre o socialismo distante da propaganda comunista e a fé cristã. Havia uma hipocrisia generalizada numa educação vitoriana numa casa onde frequentavam Pagu e Oswald de Andrade. Onde a conversa era existencialista, surrealista, moderna, livre, mas a vida em família era regida pelos princípios de colégio de freiras (MACHADO, 1991, p. $32)$.

Os anos 1949 e 1950 a futura autora e diretora passou na Europa, graças a uma bolsa de estudos conquistada para estudar teatro. Foi aluna do ator e diretor Jean-Louis Barrault em aulas de improvisação e mímica, além de ter tomado contato com produções e grupos teatrais da França, Itália, Inglaterra etc. No mesmo período, realizou, a convite da UNESCO, um curso de férias em Devon, Inglaterra. Machado voltou da Europa em decorrência de um convite para participar de um longa-metragem nacional a ser gravado pela Companhia Cinematográfica Vera Cruz. O filme Ângela foi rodado em Pelotas e representava uma grande oportunidade para a sua formação como atriz.

\begin{abstract}
Mas tudo aconteceu errado a não ser o maravilhoso que foi conhecer Pelotas, as estâncias, a vida dura de uma filmagem e sentir na pele uma briga desagradável entre Alberto Cavalcanti e Martim Gonçalves de um lado e o novo diretor do filme, Tom Payne, do outro. Os dois primeiros deixaram o filme, que continuou com enormes sacrifícios para mim que naturalmente tomei o partido do Cavalcanti (MACHADO, 1991, p. 33).
\end{abstract}

O sonho de O Tablado, de acordo com relato de sua precursora, nasceu em 1951. Por conta das visitas de vários estudantes da PUC-RJ à 487, entre eles João Sérgio Martinho Nunes, Jorge Leão Teixeira, Nilo Vasconcellos, Stélio Roxo, além de Martim Gonçalves, já distante do cinema, aconteceu a fundação desse grupo amador. O objetivo era montar os melhores textos internacionais, já que seus integrantes eram fortemente influenciados por encenações europeias acompanhadas em apresentações no Teatro Municipal do Rio de Janeiro. Machado ressalta que, nesse começo, todos exerciam todas as funções: eram maquinistas, costureiros, pintores, contra-regras.

Entre as montagens das quais Machado participou como atriz, destacam-se: Sara e Tobias, de Paul Claudel, com direção de Martim Gonçalves; Sganarelo, de Molière, com direção de Brutus Pedreira; Nossa cidade, de Thornton Wilder, com direção de João Bethencourt; $O$ tempo e os Conways, de Priestley, com direção de Geraldo Queiroz; Living Room, de Graham Greene, com direção de Alfredo Souto de Almeida; Dona Rosita, a solteira, de Lorca, com direção de Sergio Viotti, dentre outras. A grande vantagem que $\mathrm{O}$ Tablado levava em relação aos outros grupos era o fato de que possuía uma sede: "devemos isto a dona Helena Bahiano, diretora do Patronato, que acreditava 
na educação pelo teatro, nos cedendo o então salão de festas, e a Maria Luiza Delmare, a eterna e querida Lulu, casamenteira e amiga que até cafezinho servia ao público nos primeiros espetáculos" (MACHADO, 1991, p. 247).

Teriam facilitado a implementação de $\mathrm{O}$ Tablado os interesses filantrópicos do Patronato Operário da Gávea, instituição de assistência à infância desvalida que acreditava no potencial socioeducativo do teatro para crianças.

Machado, no mesmo período, dividiu as tarefas de O Tablado com os cargos de funcionária pública e professora, chegando ao cargo de diretora do Conservatório de Teatro em 1963 e secretária-geral do Teatro Municipal do Rio de Janeiro, a convite de Carlos Lacerda. Dois anos se passaram até ser afastada do cargo acusada de comunista, por ter suas peças representadas na Rússia, além de permitir que grupos de esquerda as representassem no Rio de Janeiro.

Nos primeiros dois anos do grupo ainda não fazíamos teatro para crianças. No Natal de 1953 queríamos dar alguma coisa às crianças das favelas que nos rodeavam. Kalma Murtinho, então já figurinista e atriz, sugeriu que eu adaptasse $O$ Boi e o Burro a Caminho de Belém que havia escrito para bonecos. Adaptei e foi um sucesso (MACHADO, 1991, p. 251).

A convite de Dom Hélder Câmara, o grupo aceitou levar a montagem aos subúrbios do Rio de Janeiro, em um tablado armado nas praças, experiência que segundo Machado foi inesquecível.

Classificada pela autora como uma farsa-mistério de Natal, de simples carpintaria teatral, $O$ boi e o burro a caminho de Belém narra a história de um boi e um burro que percebem coisas diferentes acontecerem no caminho de Belém, como uma estrela parar exatamente sobre seu estábulo, um cheiro doce tomar conta do ar e três Reis Magos caminharem com presentes nas mãos. Desconfiam, e ao mesmo tempo anunciam, que algo lá acontecerá. Trata-se, como sabemos, do nascimento do menino Jesus. A peça retrata os valores cristãos por meio de ação teatral recheada de músicas e partituras corporais que, em grande parte da narrativa, se sobressaem em relação aos diálogos. O texto é ilustrado com indicações cenográficas, de figurinos e partituras musicais. Maria Clara Machado insere na história tradicional do nascimento do Menino Jesus três Rainhas Magas, que acompanham os três Reis Magos. Ao som de Noite Feliz, ao fim da narrativa os atores-personagens constituem um presépio vivo.

Estava inaugurada a empreitada de O Tablado no campo do teatro infantil.

\section{A perspectiva psicanalítica como matriz balizadora da vida}

Segundo Maria Clara Machado, Pluft, o fantasminha nasceu de sua imaginação pura e simples. Foi algo inventado pela autora na hora, sem nenhum resquício de leituras passadas.

Pluft foi escrita em vinte dias. Na época, um namorado embarcou para os EUA e aquilo me fez cair na maior depressão. Escrevi Pluft tomada de angústia, como terapia, para esquecer a dor da separação de um namorado. Como outras peças minhas, Pluft foi fartamente interpretada pelo meu analista (Carlos Byington). Segundo ele, Pluft é a falta da minha mãe. A Sra. Fantasma representa a mãe ausente e Pluft o medo de crescer, de largar a saia da mãe, de ir para o mundo. 
Pluft tem a minha cara. Inconscientemente, nunca mais quis sair daqui. Nunca quis me profissionalizar, porque se quisesse, doidinha como era, teria ido (MACHADO, 1994, p. 20).

Surge, nesse ponto, uma figura constantemente citada por Maria Clara Machado, responsável pela análise e interpretação dos impulsos que a teriam motivado a criar suas dramaturgias e encenações. Trata-se de seu analista, Carlos Byington. O psicanalista de raiz junguiana justificaria por meio do perfil da mulher subestimada, a tomada do feminino por mentores masculinos.

Muito sumariamente, poderíamos dizer que a mulher brasileira padece cronicamente ainda da canga do patriarcado. Seu intelecto subdesenvolvido vai buscar alimento espiritual nos políticos reformados, padres, educadores e psicólogos, mais inteligentes e "prá frente". Isso está tornando a mulher brasileira cada vez mais evoluída que o homem, mas não rompe o cativeiro existencial que reside, a meu ver, principalmente na estrutura atual da família. Acredito que enquanto a mulher não tiver profissão e independência econômica, sua função de empregada do marido e dos filhos continuará. E é nessa manipulação pela indústria da "beleza", atestado permanente de sua condição de "boneca" e objeto e adôrno para uso sexual (BYINGTON apud HIRST, 1970, p. 2).

Sobre a profissionalização de O Tablado, complementa a autora e diretora:

Geraldo Queiroz, Carmem Sylvia Murgel, Cláudio Corrêa e Castro, Kalma Murtinho, Emílio de Mattos, todos importantes componentes do grupo, quiseram profissionalizar O Tablado em 1958. Foi uma terrível discussão. Era natural que os jovens atores quisessem se profissionalizar. Ganhar dinheiro, fazer carreira; mas eu achava que a profissionalização acabaria com o grupo. Os custos das montagens estavam cada vez mais altos. Compor música, fazer cenários, figurinos, já nos custava muito. Pagávamos ao Patronato uma pequena quantia, além da conta de luz e de telefone. Os técnicos começaram a ganhar também: cenógrafo, figurinista; Kalma Murtinho, Anna Letycia, Joel de Carvalho, Napoleão Moniz Freire, Maurício Sette e outros (MACHADO, 1991, p. 252).

Esse contexto resultou no desligamento de diversos integrantes, interessados em fundar companhias profissionais. Entre esses, saíram Claudio Correa e Castro, Kalma Murtinho, Carmem Sílvia Murgel e Geraldo Queiroz, para juntos fundarem o Teatro da Praça. Para Machado, a saída desses integrantes comprometeu a qualidade artística já conquistada pelos espetáculos do grupo. Onde encontrar bons atores? O Conservatório de Teatro, onde Maria Clara Machado dava aulas, proibiu os alunos de ingressarem em outros grupos. A necessidade de formar novos atores fez com que a diretora começasse a dar aulas de teatro no próprio palco de O Tablado, oficializando em 1964, ano da morte de seu pai, o primeiro curso de improvisação do grupo.

Outra importante ação atrelada à formação em teatro empreendida pelo $\mathrm{O}$ Tablado foi a criação, em 1956, dos Cadernos de Teatro. A iniciativa teve como inspiração os Cahiers d'Arts Dramatique de Léon Chancerel, aos quais Machado teve acesso na França na década de 1950. 
Fundamos em 1956 os Cadernos de Teatro. Nosso primeiro pensamento foi para os grupos novos que se iam formando pelo interior do Brasil, sem conhecerem nada das técnicas teatrais. Nosso lema era Remember Amapá, em inglês mesmo, para evitar a tentação de escrever artigos complicados. Queríamos ensinar o bê-a-bá da técnica. Como fabricar um refletor, uma resistência, noções de direção e de interpretação, a carpintaria do palco, a construção dos cenários. Pequenas peças traduzidas ou adaptadas (MACHADO, 1991, p. 255).

Um encarte editado pelo Sesc-SP na ocasião do ciclo de atividades, realizado em 1994, em comemoração à Maria Clara Machado, intitulado Um passeio pelo teatro infantil de Maria Clara Machado, aponta o seguinte:

É preciso lembrar que, mesmo em meia à crise, a companhia não deixou de produzir as suas pérolas. Sob a direção, respectivamente, de Alfredo Souto de Almeida, Sérgio Viotti e Yans Michalski, Maria Clara Machado agradou muito em Living Room (Graham Greene), Dona Rosita, a Solteira (Garcia Lorca) e O Mal Entendido (Alberto Camus). Em 1966, a atriz e diretora viria a escrever seu primeiro texto para o teatro adulto, intitulado As Interferências. Quatro anos depois, comporia Os Embrulhos, ainda transitando pelo terreno do teatro do absurdo. Única herdeira do espólio tabladiano, Maria Clara passou a ser o próprio Tablado, atuava, escrevia, dirigia, liderava o grupo e, principalmente, bancava as novas produções, engordando o caixa quase sempre na lona - com os sorridentes borderôs de peças infantis como Pluft e $O$ Rapto das Cebolinhas, que, àquela altura, já arrebanhavam grande público. A vocação didática foi tomando corpo. À princípio, por necessidade. Depois, por messianismo (MACHADO, 1994, p. 21).

Machado se refere ao começo dos anos 1970 como um período em que ferviam ideias políticas de esquerda, às quais não se engajava. Por esse motivo, O Tablado era considerado por muitos como uma coisa bonita, mas do passado, sem o engajamento político inerente a grande parte dos novos grupos fundados na época e cheios de ideias inovadoras. Sobre isso, formula Claudia de Arruda Campos (1998) que, se mantendo em atrito com as formas de organização e realização teatral profissional nos grandes centros, $\mathrm{O}$ Tablado ficava à margem do movimento teatral geral. Assim, suas características o sitiavam antes no campo da conservação que da renovação, fato que gerava constantes críticas divergentes sobre os seus trabalhos.

A maneira que encontrei inconscientemente para resistir à onda de repressão que tentava destruir a cultura no Brasil foi através de minhas peças. $\mathrm{O}$ ato político não precisa ser necessariamente um ato revolucionário. Não tinha e não tenho a menor vocação para fazer revolução, mas através do teatro, mesmo infantil, podemos denunciar, ridicularizar e opor-se à repressão (MACHADO, 1991, p. 256).

Ainda sobre a década de 1970, Machado considerava como um período muito difícil para ela, anos do começo das drogas, da maconha proibida, das viagens de ácido etc. Para enfrentar esse contexto, a autora e diretora enfatiza, novamente, a importância de seu analista Carlos Byington, cujos conselhos lhe possibilitaram enfrentar com 
coragem os desmandos ocasionais de sua mente, além de, como se nota, influenciarem sobremaneira sua produção artística.

Esta fase marca a minha fúria contra o mundo, as convenções sociais, a política. Coincide com o início de minha ida ao analista. A Menina e o Vento, Marroquinhas Fru Fru, A Gata Borralheira, Aprendiz de Feiticeiro e Maria Minhoca foram feitas para criticar hábitos e costumes de época. A Menina e o Vento é pura psicanálise. Nela, jogo para cima família, tias, educação e tudo o mais. Em A Gata Borralheira esculhambo todos os valores burgueses de classe média, como a mania educada de aprender a falar francês no colégio. Aprendiz de Feiticeiro chegou a ser censurada no Rio Grande do Sul porque, a partir de uma experiência de laboratório malsucedida, transformo um militar em um burro orelhudo. Maria Minhoca também sofreu repressão só porque exagerei no ridículo da figura de um pai, o Mr. Buldog, transformando-o em completo imbecil. Mas Marroquinhas Fru Fru é a que tem a história mais engraçada para contar. Segundo meu analista, esta é uma peça sobre sexo: a angústia presente de comer, comer, comer bolo, representa o desejo sexual reprimido. Fiquei muito chocada quando me disse isso. Mas hoje morro de rir. Vai ver que é mesmo: aquela ganância de comer bolo é muito engraçada na peça, não é? (MACHADO, 1994, p. 18.).

Criança é um público maravilhoso, mas a gente deve tomar muito cuidado porque ela recebe tudo, não sabendo ainda discernir; se é coisa ruim ela capta da mesma forma que as coisas boas. Por isso é preciso fazer as coisas o mais bem feito possível, realmente o melhor, ainda mais porque as crianças não têm senso crítico. Criança é uma radiografia, bate e fica... Quando escrevo uma peça não tenho intensão de fazer nada, escrevo para meu prazer, não sou pedagoga ou mesmo psicóloga, ou melhor, posso ser uma psicóloga sem querer, escrevo mesmo no ímpeto. O Aprendiz de Feiticeiro, já é uma peça um pouco mais amarga, queixando-se do mundo, das coisas. Tenho a impressão que estou mudando muito, as peças não estão assim, como eu posso dizer, tão infantis como Pluft, por exemplo. Essa mudança acho que é devida à psicanálise, de há sete anos, e faço porque tinha crises de angústias enormes, não podia resolver minha vida sozinha, já não eram angústias existenciais que agora sei quais são, por isso as peças serviram maravilhosamente para minha análise, porque peça poética é como um sonho acordado... (MACHADO apud ALMEIDA, 1969, p. $3)$.

De um grupo amador, O Tablado se transformou, paulatinamente, em uma verdadeira escola de teatro, sendo responsável, por meio de cursos de improvisação, pela formação de novos artistas.

Em estudo acerca da vida e da obra de Maria Clara Machado, a pesquisadora Claudia de Arruda Campos (1998) define sua obra como edificada, em geral, sobre as seguintes características:

- Suas peças apresentam uma visão da criança que não resvala em imitação caricata do falar infantil, com forma de expressão tocada pelo poético (Pluft, $o$ fantasminha, A bruxinha que era boa e $O$ cavalinho azul); 
- Não submete a elaboração dramática à veiculação de princípios morais ou comportamentais, não havendo um mal a combater, mas um vício a sanar (Tribobó City);

- Estilo que explora um pouco de tudo, como narrador-coringa, teatro no teatro, cortes profundos entre uma cena e outra, números musicais, nonsense e fábula tradicional (A Gata Borralheira);

- Recusa ao maravilhoso sem sacrifício da fantasia; um universo ficcional em que não se suspendem as leis naturais, fazendo a opção pelo mundo social e não sobrenatural (A Gata Borralheira, O Patinho Feio);

- Sociedades nucleadas pela família, mas versões de famílias incompletas ou fora do padrão;

- Tema recorrente relacionado ao respeito absoluto a heranças e bens de família, não havendo para os protagonistas um sentido sumamente material nesses bens (O rapto das cebolinhas; Marroquinhas Fru Fru, O tesouro de Grão-Mongol);

- Indefinição de para qual público se direcionavam suas peças.

Machado explica sua visão de teatro infantil inspirando-se no multifacetado artista

francês Antonin Artaud.

\begin{abstract}
"Teatro é poesia em movimento no espaço", escreveu Antonin Artaud em "Le Théatre el son Double". E ainda: "teatro é uma linguagem concreta que se destina aos sentidos"... que "deve satisfazer primeiro aos sentidos"... "há uma poesia para os sentidos como há uma poesia para a linguagem". Se esta concepção de teatro revoluciona a velha ideia de que teatro é apenas literatura declamada, no teatro para crianças este princípio se aplica em toda a sua extensão. É pelos sentidos e não pela inteligência que a criança guarda suas primeiras impressões. $\mathrm{Na}$ idade em que a inteligência está apenas em desenvolvimento, é principalmente pelos sentidos que a criança chega às coisas. E que melhor meio de cultura e de educação do que o teatro "poesia em movimento no espaço", para levar a criança aos maravilhosos domínios da realidade e do sonho? (MACHADO, 1964, n.p.).
\end{abstract}

A autora e diretora teatral termina o texto acima ponderando que ação, poesia, humor e fantasia seriam, a seu ver, os ingredientes indispensáveis a uma peça para crianças, sendo que essa mistura deveria servir a uma história em que o bem fosse sempre exaltado. Sobre seu processo de criação, formula a autora:

Quando escrevo minhas peças, procuro nelas imprimir as impressões mais vivas da minha infância, a fim de que sua ação e suas palavras toquem o mais perto possível a sensibilidade das crianças. Quando as dirijo, procuro antes de tudo a agilidade e vivacidade nas marcações, que o resto, no teatro para crianças, possui uma importância particular. Tudo isto, entretanto, após os primeiros espetáculos, terá de ser adaptado à reação da platéia. $\mathrm{O}$ que apaixona no teatro para crianças é que o inesperado comportamento da assistência, dona do maior desembaraço, sem qualquer preconceito e sempre disposta a intervir no curso dos espetáculos (MACHADO, 1954, p. 11). 
Dessa forma, segundo a autora, sua obra se qualifica como um teatro que extrapolava fronteiras etárias. Críticos do período parecem concordar com o caráter abrangente das obras de Machado.

É esta densidade poética na simplicidade da palavra, esta plasticidade da imaginação, que confere aos originais de Maria Clara profundidade maior que o efeito imediato de uma cambalhota ou uma careta. Há um conteúdo em suas peças que não escapa a sábia percepção infantil, conteúdo que fêz sobreviver ao tempo as lendas e contos herdados de geração para geração, qualidade que projeta o texto junto a sensibilidade da criança de modo radicalmente oposto ao expediente casual e acrobático, incapaz de subsistir à eclosão das gargalhadas que provoca. A mensagem dessas peças, sua riqueza, fantasia, responde pela receptividade que encontram junto aos adultos. Alguém já observou com muita razão, que se torna difícil numa platéia das peças infantis de Maria Clara, em certos momentos, saber quem mais se diverte: adulto ou criança... É que o ingrediente universal da simplicidade poética, receita segura e infalível, nunca falta nesses espetáculos (G., 1956, p. 13).

\section{Maniqueísmos naturalizados: entre personagens masculinos vilões e femininos inocentes}

Sobre o trabalho de O Tablado, o pesquisador Fernando Lomardo (1994) ressalta que, ao longo de sua história, compreendida não apenas por montagens infantis, Maria Clara Machado teria somado seus esforços e interesses como diretora, dramaturga e atriz. Divisora da crítica da época no que se refere à qualidade de suas encenações, embora não veiculassem uma moral explícita, os textos da autora não fugiriam ao esquema básico do maniqueísmo presente na maior parte das dramaturgias brasileiras para crianças. Lomardo pondera que, por outro lado, seus textos e montagens seriam desprovidos do tradicional ensinamento, beneficiando-se de ação fluente e ritmada, diálogos dinâmicos, econômicos e temperados de muito bom humor, além de grande diversidade de ambientação.

Acerca dos maniqueísmos a que se refere Lomardo, a análise das peças de Maria Clara Machado revela alguns temas e recursos estilísticos que se naturalizaram ao longo da constituição do teatro infantil brasileiro. Entre eles, podemos citar a dicotomia entre bem e mal, presente de forma expressiva nas obras da autora, e que resultaram em personagens desprovidos de complexidade e facilmente encaixados no seguinte perfil: de um lado, as vítimas, e do outro, os culpados. Geralmente, essa dicotomia revela-se nas obras de Machado por meio de personagens gananciosos masculinos querendo se dar bem às custas de terceiros. Um personagem expoente do que aqui se indica é o Camaleão Alface, presente nas dramaturgias de $O$ rapto das cebolinhas, A volta do Camaleão Alface, Camaleão na lua e Camaleão e as batatas mágicas, o qual, por meio de diferentes disfarces, tenta roubar as invenções do Vovô Felício. Os três ladrões músicos de $O$ cavalinho azul também se encaixam nesse perfil: desejam roubar o cavalinho azul inventado pelo menino Vicente, com o objetivo de tê-lo como atração rentável para o circo que mantêm. A dupla formada pelo prefeito Gedemar White e D. Cafeteira, em Tribobó City, é outro bom exemplo: os dois querem roubar as terras doadas para a construção da estrada de ferro e da Estação Florida, a fim de explorarem pedras e metais preciosos presentes nesses terrenos. 
O maniqueísmo a que se refere Lomardo também se manifesta na presença constante de Deus nas obras de Maria Clara Machado. Tal presença acontece por meio de duas formas. Na primeira, temos apenas a evocação a Deus, objetivando uma explicação para algum acontecimento, ou um pedido de ajuda e/ou agradecimento, como se atesta em Camaleão e as batatas mágicas, peça na qual Vovô Felício justifica sua descoberta por batatas que podem nascer em solos secos e em um mínimo de tempo como a manifestação de um dom dado por Deus a ele para que ajudasse a extirpar a fome no mundo. Já a segunda forma manifesta-se por meio de narrativas inspiradas ou estruturadas sobre temáticas bíblicas e/ou religiosas, como em $O$ boi e o burro a caminho de Belém, O embarque de Noé e Jonas e a baleia. A primeira narrativa, conforme já visto, é uma farsa-mistério de Natal que conta a noite do nascimento do Menino Jesus pela perspectiva de um burro e de um boi presentes no estábulo em que o acontecimento bíblico teria se dado. Já a segunda narrativa estrutura-se também sobre um acontecimento bíblico, o dilúvio e a Arca de Noé, colocando em fricção duas ideias opostas: de um lado, o temor a Deus e as consequências de um possível desrespeito aos seus preceitos, e, de outro, o questionamento acerca da bondade de Deus, explicitado pela fala de Cam, filho de Noé: "Deus não ama os homens, meu pai. Deus fez o senhor de bobo" (MACHADO, 2009d, p. 203). Em Jonas e a baleia, Maria Clara exibe a narrativa, também bíblica, de Jonas, escolhido por Deus para fazer os habitantes de Nínive mudarem seus hábitos. Entretanto, Jonas não desejava ser esse escolhido. Castigado, é jogado ao mar e engolido por uma baleia. Assim, Jonas se arrepende: "Enquanto o senhor me acusa, estou aqui sozinho neste escuro, dentro da barriga de uma baleia, no fundo do mar, e o povo de Nínive lá fora continua a brigar. Me perdoe, me perdoe, me perdoe, Senhor. Prometo que de agora em diante vou saber ouvir ao Senhor!" (MACHADO, 2009f, p. 303).

Outro aspecto constante na obra de Maria Clara Machado é o perfil traçado para a mulher: geralmente personagem submissa ao homem, inocente e reservada às tarefas do lar. Isso está presente, por exemplo, em $O$ rapto das cebolinhas, por meio da fala de Maneco sobre sua irmã Lúcia: "Você é muito boazinha, Lúcia. As mulheres não podem ser detetives por isso. Acham todo mundo inocente. Um detetive precisa ser meio ruim, desconfiar até do próprio cachorro..." (MACHADO, 2009c, p. 31). Outro exemplo em que essa característica emerge é em $O$ dragão verde, narrativa na qual o rei resolve dar a mão de sua filha ao cavalheiro que conseguir matar o grande dragão verde, o qual aterroriza a cidade, mesmo sendo essa uma decisão contrária à vontade da princesa. $\mathrm{O}$ rei ressalta as qualidades de sua filha: bela, prendada, cose, borda, cozinha, faz tricô, joga voleibol, ama os pobres, leu $O$ Pequeno Príncipe e toca acordeom.

Em algumas de suas obras, a moral vem à tona de forma escancarada. Em $A$ bruxinha que era boa, Pedrinho diz: "grande coisa, bruxinha, todo menino deve ser bom mesmo, mas você sim é que é bruxinha, e é boazinha. Estou muito desconfiado que você é uma fadinha extraviada" (MACHADO, 2009a, p. 50). Em A volta do Camaleão Alface, o Vovô diz sobre a receita do bem-viver inventada pelo doutor Sabidoso de Sousa: "de nada adianta ter longa vida, se não sabemos vivê-la" (MACHADO, 2009d, p. 99). Em João e Maria manifesta-se o personagem pássaro acerca do destino da Bruxa: "tanto mal ela fez que bem merece a punição" (MACHADO, 2009e, p. 40). Em $O$ alfaiate do rei, ao longo do desfile oficial do rei, o qual veste uma roupa feita de rara fazenda que só as pessoas inteligentes são capazes de ver, uma criança grita que o rei se encontra nu. O povo então canta: "A verdade sempre aparece. As coisas são como são, a criança tem razão. As coisas são o que vemos, a criança tem razão" (MACHADO, 2009a, p. 270). 
Por fim, quanto aos recursos estilísticos repetidos em diversos momentos da constituição do teatro infantil brasileiro, anteriores e posteriores à Machado, podemos identificar a reiteração em sua obra dos seguintes aspectos: a presença do narrador, ainda que disfarçado em algumas dramaturgias de personagem, por exemplo em Passo a passo no paço e A Gata Borralheira; personagens humanos relacionando-se com animais dotados de atributos humanos, por exemplo em $O$ boi e o burro a caminho de Belém, Chapeuzinho Vermelho, A coruja Sofia, dentre outros; inspiração em contos de fadas, ainda que Maria Clara recrie essas narrativas a partir de elementos seus, como em Chapeuzinho Vermelho, em que o Lobo Mau não come a Vovozinha, uma vez que é capturado pelo caçador antes que isso se dê, além de A Gata Borralheira, O Patinho Feio, Os Cigarras e os Formigas, João e Maria, O Gato de Botas e A Bela Adormecida.

\section{As práticas da dramaturgia infantil e o governamento das populações: entre verdade, sensibilidade e subjetivação}

A pesquisadora Cláudia Arruda Campos (1998) evidencia ao longo de seus estudos o caráter simbólico presente em alguns textos de Maria Clara Machado. Estes, segundo certos autores, teriam inaugurado uma escrita teatral para crianças recheada de lirismo, resultando em encenações lúdicas e poéticas.

Quem lamenta a ausência do poético na linguagem de A Menina e $o$ Vento pensa em outras peças nas quais a autora soube unir linguagem e movimento de forma a criar poesia sem hipertrofiar o texto. Uma frase de Pluft ("Mamãe... acode aqui... a menina está derramando o mar todo pelos olhos") é frequentemente lembrada como representativa do tom poético da peça. E, de fato, se tem aí um exemplo dos procedimentos de Maria Clara Machado (CAMPOS, 1998, p. 171).

O simbolismo acima indicado, em um momento de forte influência da psicanálise, por exemplo, por meio da ampla divulgação da obra A psicanálise dos contos de fadas, de Bruno Bettelheim, além das manifestações legitimadoras nesse sentido vindas do analista Carlos Byington e da própria Maria Clara Machado, inspiraria leituras psicologizadas acerca de peças como Pluft, o fantasminha, $O$ cavalinho azul e A menina e o vento por parte de terceiros também.

O Cavalinho Azul pode ser uma história sobre a morte. Quem sabe pudesse vir a ser a "morte" representada pela passagem de uma etapa a outra da vida, o perder e o deixar para encontrar e ganhar, em outro estágio de desenvolvimento. É o que parece entender Denise Moreira de Souza, ao analisar esta peça junto com outras três de Maria Clara (Pluft, A Bruxinha que Era Boa, A Menina e o Vento), que classifica como histórias da "infância vivida" e nas quais pretende ver ritos iniciáticos, como perda e conquista (morte/ressurreição) de um estágio atrasado para outro avançado (CAMPOS, 1998, p. 135).

Agravaria esse contexto as apropriações recíprocas entre as nascentes práticas do teatro infantil e da Escola Nova (AQUINO; GOMES, 2019), esta última interessada na renovação do ensino brasileiro via valorização da liberdade, da autonomia, do senso 
crítico e estético, da cooperação, de uma escola sob medida para a criança, do cultivo das individualidades e da atenção aos aspectos psicológicos do educando.

Além de abrir caminho para interpretações de cunho psicológico, o simbolismo e a poesia característicos da estética de Machado também teriam sido empregados como mecanismo de disciplinarização da criança, é o que indica o trecho de uma nota do jornal Correio da Manhã:

E aqueles que com ceticismo duvidarem do poder de penetração de um teatro inspirado na poesia e pureza junto às crianças, que então compareçam uma tarde de sábado e domingo, ao Patronato da Gávea, para ver como se domam pequenos demônios com a história do fantasminha que tinha mêdo de gente... (A FORMAÇÃO..., p. 13, 2 nov. 1955).

Em 1963, O Tablado estreava sua décima segunda peça: A menina e o vento. $\mathrm{Na}$ ocasião, Maria Clara Machado fez a seguinte confissão ao jornal Correio da Manhã:

Esta experiência de nos fixarmos num gênero tão importante quanto difícil, pode durar um ano e pode ser definitivamente o caminho do Tablado. A isso só o tempo responderá. Entretanto, temos algumas certezas sôbre as vantagens de um teatro exclusivamente para a criança e para a juventude. Eis algumas delas:

1) Preencher uma lacuna no Brasil. Todo país adiantado possui diversões específicas para crianças; digo específicas e não sobras do teatro adulto irrealizado.

2) Formar platéias para evitar o crescente esvaziado de interêsse pelos espetáculos teatrais.

3) Despertar interêsse real pelo teatro. É preciso que o teatro seja uma rotina e não um acontecimento na vida da criança.

4) Prolongar êste interêsse até a adolescência através de espetáculos de maior alcance. Poderemos chegar, assim, até os clássicos (Calderon, Molière, Shakespeare) passando pelas pequenas farsas medievais.

5) Incentivar nas crianças e nos jovens a criação de grupos dramáticos nas escolas, nos clubes, etc...

6) Apurar o gôsto do espectador através de produções de melhor qualidade, evitando, assim, que educadores e diretores, em seus grupos, se contentem com produções medíocres, quer na forma quer no conteúdo (MACHADO, 1963, p. 8)

As escolhas estéticas e políticas da artista carioca, aos olhos do presente podem soar como passíveis de serem questionadas e estranhadas. A questão é: independentemente do pano de fundo pinçado do interior da obra de Maria Clara Machado a estruturar a presente reflexão, de forma ampla, a crítica que anima este estudo é da ordem da abordagem das práticas teatrais, não raro associadas a outras práticas, sobretudo educativas e psicológicas, como campo privilegiado de governamento das população via o investimento no indivíduo.

Intentou-se aqui, como sugere Veyne (2009), enxergar pelas lentes através das quais, em cada época, os mortos rememorados, na toada de seu próprio tempo, tiveram certa percepção das coisas, como eles pensaram e agiram. Os artistas da primeira metade do século XX creram no valor moral e didático do teatro infantil com a mesma 
convicção que seus atuais fazedores acreditam no potencial libertário e emancipatório de suas práticas; cada um a seu tempo, vivendo não mais que daquilo que seus pares fizeram/fazem e disseram/dizem como verdadeiro, portanto. Nosso presente não é nem mais nem menos verdadeiro que nosso passado. Cada qual tem e teve o tamanho que o tempo vivido permitiu e permite ter. Logo, as reflexões acima rascunhadas, na tentativa de apresentar uma possibilidade de leitura acerca do passado aguardado, justificam-se por evidenciarem a singularidade e a arbitrariedade de alguns aspectos constitutivos da obra de Maria Clara Machado.

Machado e seu teatro simbólico, nascido no interior de um projeto cristão de assistência à criança desvalida, interessada em algo entre a educação dos sentidos e o autoconhecimento, via uma espécie de psicanálise da cena e, por isso, tendo seu psicanalista, Carlos Byington, como o catalisador desse movimento, o cabeça-alta de um coro que lançaria mão da psicologia como perspectiva balizadora da vida, poderia endossar, ainda hoje, a constituição de indivíduos dóceis à premissa da mulher como sexo frágil e da arte como prática complementar ao consultório psicológico.

O contrário disso, ou seja, o despertar da consciência de indivíduos, viventes do presente, que insurgiriam contra a imagem da mulher subalterna, por exemplo legitimados pelos jogos de verdade relativos aos movimentos feministas, ou então opositores de uma abordagem psicologizada da vida, também poderiam ser, dessa vez pelo avesso, discussões contemporâneas disparadas pelo legado de Maria Clara Machado em processos artísticos e ou educativos que se perfazem das práticas teatrais.

Seja por meio de uma ou de outra perspectiva, o que se infere é que estariam em operação jogos de veridicção preocupados nas oposições entre falso e verdadeiro, entre a forma mais e menos correta de conduzir as condutas, interessados em alterar a maneira pela qual seria possível pensar-se sobre si e sobre os outros, a partir de valores, de leis e de demais diretrizes existenciais. De forma geral, para além da obra de Machado, no campo da dramaturgia, da encenação ou da pedagogia do teatro, seja tomando como exemplo as práticas de uma referência icônica do campo, afiançando valores e pressupostos lá presentes, ou, ao contrário, refutando tal legado, a discursividade atinente às práticas teatrais é passível da constituição de sujeitos imbricados a jogos de veridicção. Não há neutralidade de posicionamento e de visão sobre o mundo no que tange à criação artística - neste caso, teatral. Logo, faz parte desse processo endossar certas verdades em detrimento de outras, ou seja, operariam no interior das práticas teatrais, na mesma medida que nas práticas educacionais, jurídicas e médicas, comandos de condução da conduta de si e dos outros.

Isso colocaria sob suspeita a premissa, desde há muito tempo cantada em verso e prosa pelos artífices do teatro, de que suas práticas desencadeariam incontestes processos emancipatórios, culminando em autonomia e liberdade irrestritos aos seus praticantes. Se alguma liberdade restaria a esses sujeitos, conforme nos demonstra Rose (2011), essa seria da ordem de uma liberdade cerceada, já que seu governo estaria atrelado às escolhas livremente e voluntariamente operadas por eles mesmos, atravessados em suas existências por distintos regimes de verdade, rumo à absoluta busca por felicidade, autoestima e autorrealização.

Foucault nos lega que nos jogos entre a liberdade, o sujeito e o saber-poder, quanto maior a regulação que recai sobre o indivíduo, atingindo seus desejos e concepções de mundo, maior também a sua sensação de liberdade, já que a administração desses comandos ao qual se sujeita é autorregulada por si. Ao sujeito restaria somente a liberdade de escolher ser governado de uma ou de outra forma (FOUCAULT, 1990). Quiçá as práticas teatrais, em seus diferentes fazeres, inclusive o exercício da dramaturgia, arquivo material e simbólico de um tempo, possam contribuir 
para a consciência dessa escolha, não pela perspectiva artificial da outorga de uma liberdade irrestrita, mas sim pelo trabalho crítico sobre a condição de uma escolha cerceada, já que subjugada a comandos integrados de regimes de verdade de distintas ordens.

Referências:

A FORMAÇÃO DE UMA PLATEIA. Correio da Manhã, Rio de Janeiro, ed. 19205, $1^{\circ}$ Caderno, p. 13, 2 nov. 1955.

AQUINO, J. G.; GOMES, S. S. Uma Breve Genealogia do Teatro e Educação no Brasil: o teatro para crianças. Revista Brasileira de Estudos da Presença, Porto Alegre, v. 9, n. 1, e. $82416,2019$.

ALMEIDA, M. de L. Maria Clara na primeira pessoa. Correio da Manhã, Rio de Janeiro, ed. 23440, Caderno Feminino, p. 3, 14 set. 1969.

CAMPOS, C. de A. Maria Clara Machado. São Paulo: Edusp, 1998.

CASTRO, E. Vocabulário de Michel Foucault: um percurso pelos seus temas, conceitos e autores. Belo Horizonte: Autêntica Editora, 2016.

HIRST, M. Mulher: Mitos e mistérios. Correio da Manhã, Rio de Janeiro, ed. 23567, Caderno Anexo, p. 2, 14 fev. 1970.

FOUCAULT, M. Ditos \& escritos IV. Rio de Janeiro: Forense Universitária, 2006.

FOUCAULT, M. L'archéologie du savoir. Paris: Gallimard, 1984.

FOUCAULT, M. Qu'est-ce que la critique? Bulletin de la Société Française de Philosophie, Paris, v. 84, n. 2, p. 35-63, 1990.

FOUCAULT, M. Tecnologias de si. Verve, São Paulo, n. 6, p. 321-360, 2004.

FOUCAULT, M. Technologies of the self. In: MARTIN, L.H.; GUTMAN, H. \& MILLER, P. (orgs.). Technologies of the selfs. Londres: Travistock, p. 16-49, 1988.

FRANCIS, P. A Gata Borralheira. Última Hora, Rio de Janeiro, ed. 00830, p. 43, 16 abr. 1962a.

FRANCIS, P. A Gata no Tablado. Última Hora, Rio de Janeiro, ed. 00831, 17 abr. $1962 b$.

G., J. O Chapeuzinho Vermelho. Correio da Manhã, Rio de Janeiro, ed. 19487, $1^{\circ}$ Caderno, p. 13, 3 out. 1956.

GOMES, A. C. M. Teatro infantil: uma arte séria. Correio da Manhã, Rio de Janeiro, ed. 22892, Caderno Feminino, p. 3, 19 nov. 1967.

LOMARDO, F. O que é teatro infantil. São Paulo: Brasiliense, 1994. 
MACHADO, M. C. A bruxinha que era boa e outras peças. Rio de Janeiro: Nova Fronteira, 2009a.

MACHADO, M. C. A menina e o vento e outras peças. Rio de Janeiro: Nova Fronteira, 2009b.

MACHADO, M. C. Entrevista com Maria Clara Machado. Revista do evento "Maria Clara Clareou”. SESC-SP, São Paulo, 1994.

MACHADO, M. C. Eu e o teatro. Rio de Janeiro: Agir, 1991.

MACHADO, M. C. Pluft, o fantasminha e outras peças. Rio de Janeiro: Nova Fronteira, 2009c.

MACHADO, M. C. O cavalinho azul e outras peças. Rio de Janeiro: Nova Fronteira, 2009d.

MACHADO, M. C. Os cigarras e os formigas e outras peças. Rio de Janeiro: Nova Fronteira, 2009e.

MACHADO, M. C. Maria Clara fala sobre o teatro infantil. Correio da Manhã, Rio de Janeiro, ed.18836, $1^{\circ}$ Caderno, p. 11, 21 ago. 1954.

MACHADO, M. Cl. Teatro para Crianças. Cadernos de Teatro. Rio de Janeiro. O Tablado, 1964, n. 2, n.p.

MACHADO, M. C. Tribobó City e outras peças. Rio de Janeiro: Nova Fronteira, 2009f.

RESENDE, A. (org.). Michel Foucault: o governo da infância. Belo Horizonte: Autêntica Editora, 2015.

ROSE, N. Inventando nossos selfs: psicologia, poder e subjetividade. Petrópolis: Vozes, 2011.

VEYNE, P. Foucault, o pensamento, a pessoa. Lisboa: Edições Texto e Grafia, 2009.

Recebido em 30 de maio de 2019

Aceito em 07 de julho de 2019 